\title{
Helmand River
}

\author{
Mohammad Raheem Khaksar* \\ * Department of Geography, Sayed Jamaluddin Afghan University, Afghanistan \\ DOI: $10.29322 /$ IJSRP.10.02.2020.p9822 \\ http://dx.doi.org/10.29322/IJSRP.10.02.2020.p9822
}

\begin{abstract}
Afghanistan is a mountainous country which has six neighbors. Out of those six neighbors, Afghanistan share border with five of them through water. Afghanistan share border with Tajikistan through (Ammo) domain and then water of Ammo domain goes to Uzbekistan and Turkmenistan. The domain of Havirovd Marghab connects Afghanistan with Iran and Turkmenistan. Helmand River domain connects Afghanistan and Iran, and Kabul river domain connects Afghanistan with Pakistan. Helmand River is one of the abovementioned Rivers of Afghanistan, which flows (95\%) inside Afghanistan and somehow it is being used. Helmand River is known as the biggest resource of water electricity in Afghanistan. This river plays a significant role in the prosperity of Afghanistan and Iran. This river has (262341) km length and has the capacity to irrigate (45\%) land of Afghanistan. The dam of Kajaki is a part of Helmand River and the biggest resource of electricity of Helmand domain. This dam can produce (33000) km electricity per hour. But, the water of this river has not been used. As it should have been used. Day by day the capacity and quantity of this river's water is decreasing so, this investigation provides information about the benefits and values of Helmand River.
\end{abstract}

Index Terms- Helmand, Dam of Kajakai, Sistan desert, Helmand domain

\section{INTRODUCTION}

$80 \%$ land of Afghanistan is mountainous, 63\% out of $80 \%$ has been occupied by high mountainous, which is located 300 to $600 \mathrm{~m}$ above the sea level. This range of mountains has huge ice bounds, which pay the way for the rivers and flowing water in Afghanistan. The water of the biggest rivers of our country for example (Kabul) Helmand, and Ammo flow out to foreign countries, and play a big hand in the prosperity of those countries unluckily, the water of our country is not being used appropriately. Afghanistan has 200 rivers, 25 of them are big rivers which constantly flow. Afghanistan which is located between south and middle Asia is a home to many conflicts over water than other countries of the world. There is a great probability of conflicts over water between Afghanistan and middle Asia countries. The chance of conflicts over with Iran, Pakistan, Tajikistan, Uzbekistan and Turkmenistan is specifically very high.

\section{Objectives of the Study:}

1. To accurately studythe volume of water flowing through Helmand River.

2. To study the worth and benefits of Helmand River.

3. To find how to establish good water management system in the country.

\section{Questions of the Study}

1. What type of benefit can be taken from the water of Helmand River?

2. What is the current situation of Helmand River?

3. How much land of our country is being irrigated by Helmand River?

\section{LITERATURE REVIEW}

Helmand River irrigates (40\%) agricultural land of our country, and this amount can be increased. Helmand River is a good resource for (Sistani, Iran) and Baluchistan province. (Azim, 1391, P 238). Helmand River covers from (28-31\%) population of our country, and it forms $11 \%$ of total flowing water. It covers 22 people in on $\mathrm{km}$ area, and the total amount of water of this river is 9 billion m3. (Ariz, 1390, pp). The lands which are being irrigated by Helmand River along the year, give good product" (Azim, 1390, Pp77-78). Helmand River is one of the biggest rivers of Afghanistan and Asia. Annually this river produces milliard $\mathrm{m} 3$ water and is known as the huge river between Indus and Euphrates rivers (Mahdizada,2008, p79).

The well-known historian of Afghanistan Abdulhay Habibi entitled Helmand River as Hermand River in his master price (1354, p155). Annually, Helmand River has $(9,3)$ milliard $\mathrm{m} 3$ water, which forms $16 \%$ of the total amount,only (4-5) milliard $\mathrm{m} 3$ of this water is utilized (Nasrati, 1393, p189).

\section{DATA AND METHODOLOGY}

Every researcher needs the necessary data and devices during the research. In the beginning the researcher has collected information about Helmand River from different books, after study the researcher has separated relevant and irrelevant topics from each other. The researcher has also cited the necessary topics under the specific tittles. The researcher had some problems in the process of collecting information, because only a small amount of research and studies have been conducted about Helmand River before. This is an analytical article. In this article the researcher has collected information from books, magazines, journals, etc. the researcher has analyzed this article and written a conclusion on its and this is an applied research. 


\section{A. The Benefits of Helmand River Cultivation}

Water play vital role for the improvement of cultivation and agriculture. Several projects have been founded in Afghanistan for the advancement of agricultural activities and production of energy, for instance the dames of Ghazi, Qarghi, Sultan, Sard, Pararood, and the projects of Nadali,Nahri sarj Darveshan, Khansheen etc. Despite the establishment of those projects still (50-75\%) land of our country either suffer the lack of water. Using the existing resources of water appropriately increases the amount of production. For that reason, to make new water dams and bring reforms in the system of irrigation and cultivation.

Helmand River is one of the biggest rivers of the country and covers half of the part of Afghanistan during the year, this river flows distort so it is not used properly. In after times people who lived in those areas suffered from the lack of water, so the government decided to make some dames and streams. So, for reaching to this purpose, the started some developing projects over Helmand River, for example Baghra, Margi, Nadali and so on. At the moment Helmand River can irrigate (386000) km land. If the water of this river is managed and used accurately, it can irrigate more land than $(38600 \mathrm{~km}$,) and the remaining water should be sent and sold to Iran. Helmand River in Sistani are and through it. They produce; earn wheat, watermelon and graphs etc. (http // www. Wolas - ghag .com)

Helmand River also paves the way for too much agricultural land to be irrigated. Along its way many developing projects have been founded, which boost the sector of cultivation, the dam of Nadali has been built over Helmand River, which irrigates (8900) hectare of land. Out of this dam. Irrigate $(6700 \%)$ hectare land of Nada Ali and (2200) hectare land of Babaje district. The water of this project is taking from Helmand River by Bajhra stream. The abovementioned dam has (314) km length and has been using so far.Marja is another dam, which has been built over Helmand River. Marja has $(192 \mathrm{~km})$ length and has the capacity to irrigate (8100) Hectare land. Helmand River also irrigates (1000) hectare land in Grashak district and improves daily. A lot of agricultural land has been discovered with the establishment of Shamalan cannel, this cannel is known as the big reason for the beauty of this area. Darwishah is another dam, which takes its water from Helmand River, and has the capacity to irrigate land of (20300) hectare.

Nehari siraj is other dam which uses the water of Helmand River. Based on some accounts, this dam irrigated (24000) hectare land in. And it has to (6700) at the movement; wild environment and the fast evaporation of water are the problem for this dam. Helmand River also irrigates (400000) acre land underneath Kajakai, which ensures a good production during the year. Helmand River has too many benefits for instance, it irrigates the land for cultivation, boost the capacity of water electricity and plays key part in the cultivation of many areas and boosting national economy. If the water of Helmand |river is used appropriately, and according to the modern technology it can provide us with the following benefits.

(1) Water energy.

(2) Excavation of cannels for the expansion of cultivation.

(3) Preventing the lands from the floods.

(4) Keeping of water.

(5) Building the farms of fishes.
The improvement of jungles and parks.

The expansion of meadows, flowers and entertaining places.

Even though Helmand River is the biggest river of our country, it does not help Afghan people, because of the negligence of the government. A lot of water of this river goes out of Afghanistan and enter to Iran. At the moment the people of Farah and Nemroz suffer from the lack of usable water. Based on some reports, the people of Zarnge city buy water from the tankers, which are very expensive and unhealthy including the fact of that Helmand River makes its way and flows in this province. Unfortunately, the people of this city "Zarange" have not used the water of this river so far, either for irrigation or drinking. Some researchers say it is the negligence of Afghan government which does not have a good policy for managing the water. If the water of Helmand River is used and managed properly, it will solve many problems and improve national economy.

Many deserts exist in Afghanistan, especially along both sides of Helmand River. Those deserts are without agricultural activities and using. If the government makes dames over Helmand River those deserts will be irrigates and will solve many problems. According some accounts, at the present time about (6-9) millionhectare land of Afghanistan's and can be cultivated. Out of that ( $5 / 5$ hectare has the capacity to be irrigated, but unfortunately only $(2 / 1)$ million-hectare land of our country is being irrigated. (7\%) products of cultivation in Afghanistan come from fertilized land. Every year Afghanistan imports cultivation's goods from foreign countries about four (4) million dollars. If we spend that much money inside our country for the improvement of cultivation, this will have a good result. But unluckily, currently only (30\%) water of Helmand River is used in Afghanistan and remaining (70\%) goes to Iran and the people of Iran use it.

Iran has made water dam over Helmand river without allows of Afghans government, so if the water of Helmand River is used inside Afghanistan, it will solve many problems (Http: // www. Wolas.com). Even though, Helmand River goes through the southwestern part of our country, the people of Helmand still suffer from the lack of water. And enough water does not exist for cultivation activities. Currently $(65 \mathrm{~m} 3)$ water per second flows from Helmand River to Bajhra cannel and irrigates (70\%) land of Nadali. Currently, streams water can irrigateso thou sand acre land; however, (100) thousand-acre land is under cultivation in Nadali.

According to the officials, much of the water of those streams is used by authoritarian for the irrigation of abutted lands. On the other hand, cannels do not work well. Additionally, people do not have enough water for irrigating their lands in Marja so; the people of this area are obligated to abandon their houses and migrate to other places. At present 300 water pump has been installed along the cannel of Baghra. Those pumps extract water from Baghra and decrease the amount of water. This is unprofessional act and gives little benefits (8 Am. Of/ 1395/ 03/ dam - kajakai- Afghanistan 2/)

\section{B. The Benefits of Helmand River in the Production of Energy}

Afghanistan has many resources of energy production. The master plan of electricity energy shows that, Afghanistan has (24000) megawatts potential energy. Out of (24000) megawatts potential, 
(23000) come from the rivers. The remaining (1000) megawatts potential come from the resources of heating energy Helmand River has (2vo) watts potential, (66: v1.). Helmand River and its contributors are totally adequate for electrical energy. Generally, Helmand river has $(9,3)$ milliard, water annually. Only one milliard $\mathrm{m} 3$ of this water is used. And the remains water freely flows to Iran and plays a big hand in the prosperity of Iran.

It should be mentioned that Helmand River has the potential of (270) megawatts electricity. Now, only the amount of $(44,8)$ megawatts electricity is produced from it. If the water of Helmand River is adequately used, from one hand Afghanistan can be selfsufficient from the perspective of electricity, and from the other hand Afghanistan will be able to produce some electricity to neighbor countries. This act can convert our country to water electricity producer and exporter country.

Afghanistan is known as a country, which water electricity in the region from the neighbors, only in (1390) Afghanistan imported energy at the east of (6) milliard dollar from, Tajikistan, Uzbekistan, Turkmenistan and Iran. Helmand River is full of water, and dams can be made over it. If the government makes dams over Helmand River, it can prosper the country and improve economy. The dame of Kajakai has been built over river, which is one of the biggest establishments of electricity in Afghanistan. The abovementioned dam has the capacity to (3000) kilo watts electricity per hour. This dam helps in giving electricity to Kandahar, Grashak and Bost, and helps in industries. The dam of Kajakai is one of the largest dams of Afghanistan which does not only help in the production of electricity, but also being used in the irrigation of cultivation's lands.

The dam of Kajakai is located in 32 grades, 9 minutes and (2, (second of northern latitude, and (64) grades (46) minutes and (26) seconds of eastern longitude the agreement of building this dam came up in (19 46) by Morisson company. The location was also discoursed, marked as Helmand province, Kajakai district and next to Grashak at $100 \mathrm{~km}$. The building process of this dam started in (1950) and ended in (1952). Irrigation of lands and production of electricity were the goals of this dam. The fundamental figure of this dam was to control the water of floods and use the water of this dam when required. This dam kajakai is (100) $\mathrm{m}$ high and $(275 \mathrm{~m})$ long the length of it is $58 \mathrm{~m}$ and the width of it is $2 \mathrm{~km}$. this dam has two tunnels, one tunnel works to irrigate the land of cultivation, and the other hand is for the production of electricity (751: 3). Kajakai is a big dam in Grashak which has some characteristics as below:

1 - Height (100m).

2- The length of dam in upper area $(275 \mathrm{~m})$.

3 - The width of dam in lower is (2om.)

4- The land and sand, which have been used for full the dam is (3 million $\mathrm{m} 3$ ).

5 - The length of lake is $(58 \mathrm{~km})$.

6- The middle length of lake is $(2 \mathrm{~km})$.

7- The amount of soul and rocky material, which have been used, is $(3225000 \mathrm{~m} 3)$.

\section{Water using tunnel:}

1- The length of tunnel is $(717 \mathrm{~m})$.
2- The height of tunnel is $(1060 \mathrm{~m})$.

3- Width (10,30m).

\section{Electricity Tunnel:}

1- Length $(575 \mathrm{~m})$.

2- Height $(10,60 \mathrm{~m})$.

3- Ultimate width $(10,36 \mathrm{~m})$.

4- The amount of concrete in both tunnels is (1211m3).

5- The amount of power get from Kajakai dam is (120000) kilo watts.

The dams of Kajakai and Baghra are the biggest resources of the water, which are located over Helmand River. The dam of Kajakai has the capacity to produce (60000) kilowatts electricity and can be increased to (100000) kilowatts currently, this dam (Kajakai) has (250) million $\mathrm{m} 3$ water. If the height is increased by $10 \mathrm{~m}$, the source of water can be increased to 3 , v milliard $\mathrm{m} 3$.

Kamal Khan is another dam, which is under- work. This dam will be built over Helmand River, the construction of this dam need 78 million dollars, which will be given from the budget of Afghanistan. This is the third biggest dam in Afghanistan, which will have the capacity of 9 megawatts electricity, and will have the capacity to irrigate (80) thousand-hectare land. With the establishment of Kamal Khan Dam, the (5000) old water management system will active again in Afghanistan. The abovementioned dam is vital for Afghanistan and region, which can put impact on social and economic statues of people. Efforts are being made to accomplish the affairs of this dam ahead of time, according to the material of convention. This dam can give relief to the historical area Sistan and can change this area to the center of civilization and culture. And also, this dam can increase the credit and goes to Afghanistan and can improve the management of water. This dam, which will be built over Helmand River, in Nemroz province Chabahar Barjak area, will have lower source of water compared to the dam of Herat's Salma dam, and Farah's Baksh-Abad dam, but the quality of this dam water is very high. This dam will be built in a flat area.

According to researchers Kamal Khan dam will have the capacity to save (25) million $\mathrm{m} 3$ water and can help in the management of about (1) milliard $\mathrm{m} 3$ water. The design of building this dam was shown in the time of Sardar Mohammad Dawood Khan government (1970,) and because of civil conflicts, the design did not convert to reality. By building this dam the amount of benefits of Helmand River can be increased. The area of Kamal khan dam has little gradient and is covered by desert. The height of Kamal khan dam is $(16 \mathrm{~m})$. This dam saves little water than Salma dam, but can saves much water.

Kamal Khan dam is locating in (29) grades (2) minutes, and (57) seconds of northern longitude, and (6) grades (52) minutes and 11 seconds of eastern longitude. Kamal Khan is located $(18 \mathrm{~km})$ away from the north of Charbak district, and $95 \mathrm{~km}$ away from the capital Nemroz province Zarang (www. BBB.com/ Pashto/ Afghanistan$3965=6148$ ) the building of Kamal Khan Dam can increase the agriculture production of Nemroz province and can prevent the damages of floods. If this dam is built according to international standards it can convert Nemroz province to a source of crops. Kamal Khan dam can also give employment to unemployment, 
poor Afghans, Kamal Khan dam 3400m length 320m width and from (11- $6 \mathrm{~m}$ height and can find jobs for 100 thousand Afghans. (Www- $1 \mathrm{t} \mathrm{v}$ news.

New researches show that the annual amount of water of Afghanistan (75) milliard m3, out of that only (25or 30) milliard $\mathrm{m} 3$ is used for cultivation, and the remaining $75 \%$ which is equal with so milliard $\mathrm{m} 3$ goes out of border and flows to Pakistan and Iran. Internationally, one $\mathrm{m} 3$ water has one and a half or two-dollar cost, so recently Iran sell the water in this cost to Kowit, but the water of Helmand River freely goes and flows to Iran. If we sell our country's water to foreign country' ( $1 \mathrm{~m} 3$ per dollars) we will have (5) milliard dollar every year, which will be a huge income to Afghanistan. So, we will not need any country to help us. We can say that (5) milliard and dollar will be added to national budget which is more valuable than the gas, oil and copper of Afghanistan. As Iran recognize its oil as its national property and sell it to foreign countries, we Afghans have right to sell out water to Pakistan, Iran other northern neighbors, and boost our economy (http: //www.af.com.).

\section{RESULTS}

This article brings us to the result, that Helmand River is one of the biggest rivers of Afghanistan, but as it is appropriate, it is not being used. Currently, (30\%) water of this river is used inside Afghanistan and (70\%) goes out to foreign countries Iran use this water for the prosperity and improvement. In afore times some amount of water had flowed to some parts Afghanistan, Iran government has prevented it by making dams cover this water, so Iran brings this water through tankers and sells it to afghans people in Nemroz province big amount of water of Helmand River flows to Iran. If this amount of water is flanged and managed property, it will increase the amount of cultivating production, and it will solve the problem of electricity, and can lead Afghanistan to be a self-sufficient country so, Afghan government can use. Helmand River as a political pressure against Iran, and it is a good political device against Iran.

\section{DISCUSSION}

The result of this article shows that Helmand River is one of the biggest rivers of Afghanistan. This river covers much of the cultivating land of our country. The deserts which are located at the sides of this river are not being cultivated, because of the bad management of water. If other dams are built along this river, from one hand it will irrigate barren land, and from the other hand, it wills the capacity of water electricity.

Currently a notable change has accrued in the water of this river. The main reason of those changes is the elimination of jungles, and continuous drought. As well as, the amount of its energy production has also decreased. For instance, Kajakai dam produced (120) megawatts electricity in afore times but has decreased to (30|) megawatts recently. Generally, Helmand River has the capacity to produce (270) megawatts electricity, which shows the little usage of its resource. The amount of water which Helmand River irrigates has also changed. The best instance of this is Nehari-al -Siraj dam, which had the capacity to irrigation
(24000) hectare land - (39- ) in afore times, but has decreased to (7000), or (6700) recently.

The biggest reason of this reduction is the improvement of deserted environment and quick evaporation. Including in fact to the that Helmand River flows to the south western parts of our countries but still people suffer to the lack of water in Farah and Nemroz provinces. People buy water from the tankers of Iranian people with a very high cost and use them. If the water of this river is flanged and managed properly, so it will solve many problems. The building of Kamal Khan dam will increase the capacity of cultivating land and increase the capacity of electricity. So, this will make our country self-sufficient.

\section{CONCLUSION}

This article shoes, that Afghanistan has water's resources above and under land, from those resources. One resource is Helmand River. The water of Helmand River has not been used adequately and is used only a little bit. Despite the fact that, basic foundations, like electricity dames and other can make Afghanistan a selfsufficient country, and the problem of pollution can be eliminated. If the water of Afghanistan especially the water of Helmand River is used appropriately, so that will pave the way for the betterment of jungles, postures and other plants and trees. Including. In fact, that Afghanistan has a big amount of flowing water, this water is little used, and freely goes out to foreign countries this water plays a big hand in the prosperity of those neighbor countries.

Helmand River covers much of the land of our country, but because of little usage of Helmand River, and this land is totally deserted. During summer and spring, the water of this river gets fast, and destroys to much agricultural land. This condition gives damage to Afghanistan instead of benefits. If the water of this is used appropriately, the destruction of the land will be prevented, and on the other hand, this act will be effective for the production of electricity and improvement of cultivation. Kamal Khan Dam can increase the benefits of Helmand River. The result of this research shows that during the years of (2000-2001) the amount of this water has increase by 48 million, $\mathrm{m} 3$ that shows $(98 \%)$ reduction in its real flowing. Additionally, this research shows, that $(30 \%)$ water of this country is used inside Afghanistan and (70) water of this river flows to Iran.

\section{SUGGESTIONS AND RECOMMENDATIONS}

The following suggestions have to be presented about this research.

1- New dams have to be built along the Helmand River, to give benefits for the cultivation and electricity.

2- The dams which were built before over Helmand River have to be supervised, and its capacity has to be expanded.

3- Iran is using the water of Helmand River, and does not give any payment.

So, Afghan government has to prevent the additional water from flowing to other country. 


\section{REFERENCES:}

[1] Ahmadi, M. H. (1390). Physical Geography of Afghanistan. Kabul: Higher Education Publication, Education University

[2] Ariz, G. J. (1379). Provincial Geography in Afghanistan. Kabul: Akabar Publishers

[3] Ariz, G. J. (1383). Rivers of Afghanistan. Peshawar: Al-Azhar Publishers

[4] Aryana Encyclopedia. (1387). Second Volume, Kabul: Nabaraska Publication

[5] Aryana Encyclopedia. (1392). Fifth Volume, Kabul: Nabaraska Publication

[6] Azimi, M. A. (1390). An Introduction of Natural Geography of Afghanistan. Kabul: Amiri Publishers

[7] Azimi, M. A. (1391). A View over Afghanistan Political Geography. Kabul: Khorasan Publishers

[8] Azimi, M. A. (1395). An Introduction to National Security of Afghanistan (Geography and Life Environment). Kabul: Nigar Publishers

[9] Bakhtani, A. (1390). Flowing Water of Afghanistan and its Resources. Academy of Studies, Regional Studies Center

[10] Murad, M. Q. (1394). Water Resources in Afghanistan and Ways of its Usage. Tabeyat Academic Journal, No. 35, Kabul: Academy of Studies

[11] Nasrati, R. (1393). Condition of Hydrography in Afghanistan. Tabeyat Academic Journal, No. 32, Kabul: Academy of Studies

[12] Rahmati, M. (1999). An Introduction of General Geography of Afghanistan. Peshawar: Pakistan

[13] Shahim, M. A. (1394). A Study of Non-Utilization of Kabul Water Basin Energy.
[14] Tabeyat, Educational Journal. No. 36, Kabul: Academy of Studies

[15] Taniwal, M. Z. (1389). General Geography of Afghanistan. Kabul: Karwan Publishers

\section{Authors}

First and Correspondent author: Mohammad Raheem Khaksar

Department of Geography, Sayed Jamaluddin Afghan University 